\title{
Hexaferrite Based Flexible Polymeric Nanocomposites for Microwave Absorbing Applications
}

\author{
Azizurrahaman Ansari* \\ Department of Physics, Aligarh Muslim University, India \\ Submission: January 28, 2021; Published: February 10, 2021 \\ *Corresponding author: Azizurrahaman Ansari, Department of Physics, Aligarh Muslim University, India
}

Keywords: Nanocomposites; Microwave; Graphite; Alloys; Metal oxides; Rubber materials

\section{Opinion}

The flexible microwave absorbers are being considered as new generation materials which have wide applications in the local area network, wireless data communication, radar systems, satellite communication, satellite television, electronic devices and the heating systems, etc. A number of dielectric, magnetic, and magneto - dielectric materials are frequently used as microwave absorbers for various applications. The carbonaceous materials like carbon fiber, carbon nanotubes, graphite and graphene and inorganic materials like metals, metal oxides, and conducting alloys are used to develop the dielectric microwave absorber because of their conducting loss property. The magnetic materials like magnetic metals and their compounds are used to produce magnetic microwave absorber due to their hysteresis loss property. The combined features of the dielectric and magnetic materials together assist in the preparation of magneto - dielectric microwave absorbers. The spinel ferrites are generally employed as magnetic components for the design of microwave absorbing materials. However, the spinel ferrite based microwave absorbers have usually been reported to work at frequencies below $1 \mathrm{GHz}$. A very high amount of spinel ferrites ( $70-90 \mathrm{wt} \%)$ is required for the design of microwave absorber working above $1 \mathrm{GHz}$ frequency (for example, X-band). However, such high content of spinel ferrites makes the absorbers as heavy in weight due to which their applications in the aerospace industry are constrained. Apart from the heavy weight, the spinel ferrite based microwave absorbers are also restricted in some practical applications due to their large thickness, narrower absorption bandwidths, and the brittleness property. In order to increase the applicability of ferrite based microwave absorbers, the hexagonal ferrites (M-type) appear to be better option due to their relatively high magnetic losses resulting into broadband and efficient microwave absorber for the higher frequency applications (X-band). To circumvent the brittleness of the ferrite/hexagonal ferrite based microwave absorbers and to make them flexible, the hexagonal ferrites can be dispersed into the thermoplast polymers or rubber like host materials.

This ideology of using low density thermoplast polymers as base material also offers the advantage to minimize the heavy weight problem. In the past, a number of the researchers synthesized flexible and wideband microwave absorber for the $\mathrm{X}$-band application using the barium hexaferrite nanopowder as reinforcing element and rubber as host material. For instance, S. Vinayasree et al. reported the hybrid type flexible nanocomposite based on strontium ferrite, carbon black, and nitrile rubber materials to design microwave absorber for S- and X-bands applications [1]. A. Drmota et al. presented polyphenylene sulfide (PPS) polymer and strontium hexaferrite based composite as microwave absorber for $0-3.5 \mathrm{GHz}$ microwave frequency range [2]. S. B. Narang et al proposed polyvinyl alcohol (PVA), and Co and Ti doped strontium hexaferrite based soft nanocomposite as microwave absorber for X-band application [3]. S. Chakraborty et al synthesized flexible nanocomposites based on strontium hexaferrite nanopowders embedded in the linear low density polyethylene (LLDPE) matrix to develop microwave absorber for X-band applications [4]. From above discussion, it can be inferred that most of the flexible nanocomposites employ some kind of ferrite nanopowder embedded into either rubber or thermoplast polymers in order to design microwave absorbers for X-band applications. However, use of ferrite powder alone into either rubber or thermoplast polymers would only provide magnetic 
losses thus providing only one degree of freedom to control the total microwave absorption in the specified frequency band. The aim of this issue is to study the microwave absorbing properties of the hexaferrite based polymeric nanocomposite for their potential use in RADAR, high frequency devices, aerospace and stealth applications.

\section{References}

1. Vinayasree S, Soloman MA, Sunny V, Mohanan P, Kurian P, et al. (2013) A microwave absorber based on strontium ferrite-carbon black-nitrile rubber for S and X-band applications. Compos Sci Technol 82(8): 6975 .

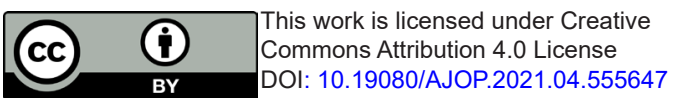

2. Drmota A, Koselj J, Drofenik M, Žnidaršič A (2012) Electromagnetic wave absorption of polymeric nanocomposites based on ferrite with a spinel and hexagonal crystal structure. J Magn Magn Mater 324(6): 1225-1229.

3. Narang SB, Hudiara IS (2006) Microwave dielectric properties of M-Type barium, calcium and strontium hexaferrite substituted with Co and Ti. J Ceram Process Res 7(2): 113-116.

4. Chakraborty S, Bhattacharyya NS, Bhattacharyya S (2016) Single layered wide bandwidth nanosized strontium hexa-ferrite filled LLDPE absorber in X-Band. Prog Electromag Res (PIER) B, 71: 137-152.

\section{Your next submission with Juniper Publishers will reach you the below assets}

- Quality Editorial service

- Swift Peer Review

- Reprints availability

- E-prints Service

- Manuscript Podcast for convenient understanding

- Global attainment for your research

- Manuscript accessibility in different formats ( Pdf, E-pub, Full Text, Audio)

- Unceasing customer service

Track the below URL for one-step submission https://juniperpublishers.com/online-submission.php 